\title{
Aspects of the marital relationship that characterize secure and insecure attachment in men and women
}

\author{
Aspectos do relacionamento conjugal que caracterizam \\ apego seguro e inseguro em homens e mulheres
}

\author{
Crístofer Batista da COSTA ${ }^{1}$ (iD) 0000-0002-1307-1436 \\ Clarisse Pereira MOSMANN'1 (D) 0000-0002-9275-1105
}

\begin{abstract}
The internalized attachment in childhood has consequences in the adult life, specifically in the marital life, which demands greater closeness, intimacy and interdependence. In this sense, it was analyzed whether the communication, marital adjustment, frequency, intensity and conflict resolution variables discriminate individuals with secure and insecure attachment in heterosexual relationships. It is a quantitative, descriptive and explanatory study. Data from 485 participants were collected in the south of Brazil through the following measures: Experience in Close Relationship, Marital Conflict Scale, Conflict Resolution Behavior Questionnaire, Communication Questionnaire and Revised Dyadic Adjustment Scale. The results of the discriminant analysis indicated that the variables tested characterize secure or insecure attachment. Therefore, the type of attachment is a relevant resource in the assessment of individual and marital functioning. Psychotherapy interventions are discussed considering the relational bias of the attachment theory and the results observed in the scientific literature.
\end{abstract}

Keywords: Communication; Marriage; Object attachment; Problem solving.

\section{Resumo}

O apego internalizado na infância provoca reflexos na vida adulta, especificamente na conjugalidade, a qual demanda maior proximidade, intimidade e interdependência. Nesse sentido, foi analisado se as variáveis comunicação, ajustamento

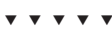

1 Universidade do Vale do Rio dos Sinos, Centro de Ciências da Saúde, Programa de Pós-Graduação em Psicologia Clínica. Av. Unisinos, 950, Sala 2A109, Jd. Itu Sabará, 93022-000, São Leopoldo, RS, Brasil. Correspondence to: C.B. COSTA. E-mail: <cristoferbatistadacosta@gmail.com>.

Article based on the thesis of C.B. COSTA entitled "Relações conjugais: análise individual e diádica entre as variáveis apego, personalidade, conflito, comunicação, resolução de conflito e ajustamento de casais heterossexuais". Universidade do Vale do Rio dos Sinos, 2019.

Support: Coordenação de Aperfeiçoamento de Pessoal de Nível Superior (Process \# 88881.135826/2016-01).

How to cite this article

Costa, C. B., \& Mosmann, C. P. (2020). Aspects of the marital relationship that characterize secure and insecure attachment in men and women. Estudos de Psicologia (Campinas), 37, e190045. https://doi.org/10.1590/1982-0275202037e190045 
conjugal, frequência, intensidade e resolução de conflitos discriminam indivíduos com apego seguro e inseguro em relacionamentos heterossexuais. Trata-se de um estudo quantitativo, descritivo e explicativo. Dados de 485 participantes foram coletados no Sul do Brasil por meio das medidas Experience in Close Relationship, Escala de Conflito Conjugal, Conflict Resolution Behavior Questionnaire, Communication Questionnaire e Revised Dyadic Adjustment Scale. Análise discriminante indicou que as variáveis testadas caracterizam apego seguro ou inseguro. Portanto, o tipo de vinculação é um recurso relevante na avaliação do funcionamento individual e conjugal. Intervenções em psicoterapia são discutidas considerando o viés relacional da teoria do apego e os resultados apontados na literatura científica.

Palavras-chave: Comunicação; Casamento; Apego ao objeto; Resolução de problemas.

Bowlby's theory of attachment (1973/2004) has been the focus of national and international studies due to the reflexes that different styles of attachment cause in the adult life (Almeida \& Caldas, 2012; Garrido, Guzmán-González, Santelices, Vitriol, \& Baeza, 2015; Guzmán-González, Carrasco, Figueroa, Trabucco, \& Vilca, 2016; Semensato \& Alves, 2013), specifically in the marital relationship (Cobb, Davila, \& Bradbury, 2001; Scheeren, Delatorre, Neumann, \& Wagner, 2015 ; Scheeren, Vieira, Goulart, \& Wagner, 2014). This assumption, combined with the Systemic and Humanistic/Existential theories, gave rise to the Emotionally Focused Therapy (Hardy \& Fisher, 2018; Semensato \& Alves, 2013; Wiebe \& Johnson, 2016), an approach that has stood out in the treatment of couples for being one of the available evidence-based therapies (Costa, Delatorre, Wagner, \& Mosmann, 2017).

The attachment style, internalized through the relationship between the child and the caregivers, is a constitutive factor of psychic functioning, composing mental representations or internal work models that will establish the conditions for the individual to seek, interpret and react to subsequent experiences (Bowlby, 1973/2004; Curran, Ogolsky, Hazen, \& Bosch, 2011). In adulthood, attachment styles are activated in close relationships that have the potential to provide affection and security (Bowlby, 1973/2004). Thus, the characteristics of the marital and spousal relationships, the responses of the environment and the presence or absence of reciprocity in the relationship can activate the internalized attachment style, triggering perceptions of greater or lesser emotional security (Consoli, Wagner, \& Marin, 2018).

The definition of attachment proposed by Ainsworth (1985) is the most used in the literature, classifying it as "secure", "insecure-anxious" and "insecure-avoidant" - styles associated, respectively, with the individual's perception of the world around him or her as secure, unstable or uncertain (Bowlby, 1973/2004). If marital conflicts represent an implicit threat to security and emotional closeness in the relationship, different attachment behaviors may be triggered, apparently related to deficits (or skills) in close interpersonal relationships and, mainly, in marital relationships (Corcoran \& Mallinckrodt, 2000; Curran et al., 2011). Some authors suggest, for example, that low levels of marital adjustment, communication problems and destructive conflict resolution strategies tend to occur among spouses who have higher levels of insecurity and avoidance when interacting in conflict situations (Cobb et al., 2001; Consoli et al., 2018; Deitz et al., 2015; Lamela, Figueiredo, \& Bastos, 2010; Mikulincer, Florian, Cowan, \& Cowan, 2002; Murray, Holmes, \& Griffin, 2000; Seedall \& Lachmar, 2016; Semensato \& Alves, 2013).

Otherwise, individuals with a role model of secure attachment turn to their spouses in times of difficulty and distress, as they trust and feel secure in their ability to help them (Bowlby, 1973/2004; Lamela et al., 2010). In addition, they are spouses who are able to explore different perspectives of conflict resolution with the spouse (Corcoran \& Mallinckrodt, 2000), and deal with the divergences that arise in the relationship in an adaptive way even if, in their childhood, they lived in contexts with high levels of marital conflict, since they are able to remember and understand past experiences and differentiate themselves (Curran et al., 2011; Walsh, 2016). Finally, individuals with secure attachment tend to positively assess the various aspects of the marital relationship and to be resilient to the difficulties inherent to the life of a couple

2 (Mikulincer et al., 2002). 
If the pattern of attachment is insecure-anxious, the individual will have doubts about the availability of the other one and will feel unassisted, rejected and abandoned, reacting through jealousy, distrust and stalking. The focus of attention tends to be at the source of suffering, particularly if the attachment reference does not match their needs. If the pattern of attachment is insecure-avoidant, the result will be less affective proximity, excessive independence, absence of empathy, responsiveness and availability. The focus of attention is diverted from what causes distress and emotional control and avoidance strategies tend to be used (Mikulincer et al., 2002; Murray et al., 2000).

A study carried out in the city of Los Angeles (USA), with 172 newly married couples at six and 12 months after getting married, evaluated a mediation model in which positive perceptions about the spouse's way of being were associated with adaptive support behavior, which would be a predictor of increased marital satisfaction (Cobb et al., 2001). The results indicated that positive perceptions were associated with the behavior of giving and receiving support from the spouse. Individuals who perceived a secure attachment style in their spouses, regardless of whether the perception of security is real or not, demonstrated a greater capacity to resolve conflicts constructively, accept help from the other one and be less critical and pessimistic.

In China, researchers analyzed the associations between the family dysfunction, marital satisfaction, trust in the spouse and conflict resolution variables and the insecure-anxious and insecure-avoidant variables in a sample of 189 young adults. The results indicated that the marital satisfaction of men depended on intrapersonal factors and that of women on interpersonal factors arising from interaction. In addition, family dysfunction associated with higher levels of avoidant attachment correlated with lower levels of marital satisfaction while family dysfunction, associated with higher levels of anxious attachment, correlated with the worst results for conflict resolution (Deitz et al., 2015).

In the Brazilian context, the predictive role of attachment styles was tested in resolving marital conflicts of 428 participants, 214 men and 214 women, and results indicated that the insecure-anxious attachment style was a predictor of a destructive conflict resolution approach, while secure attachment was a predictor of a constructive resolution approach for men and women (Scheeren et al., 2015). Another Brazilian study (Consoli et al., 2018) investigated, in a sample of 100 heterosexual couples, the relationship between the primarily attachment pattern and the one established between spouses, and the influence on marital adjustment. The study revealed that the primarily secure attachment pattern was associated with lower levels of avoidance between the couple and well-adjusted, painless relationships. The primarily insecureanxious and insecure-avoidant attachment styles have been associated with higher levels of avoidance, and imbalanced, painful relationships.

Different studies show that the attachment style, as an independent variable, predicts the type of strategy that will be used by spouses (Ricco \& Sierra, 2017), marital quality (Scheeren et al., 2014; Scheeren et al., 2015), as well as marital status adjustment (Cobb et al., 2001; Consoli et al., 2018; Epstein, Warfel, Johnson, Smith, \& McKinney, 2013), a variable that assesses how well adjusted the couple is through levels of satisfaction, consensus and cohesion (Hollist et al., 2012). As initially mentioned, attachment styles influence the way people perceive their spouse and conflict situations, interpret events in the relationship and behave towards them, interfering in the way they communicate, demonstrate their needs, resolve conflicts and assess the relationship (Cobb et al., 2001; Curran et al., 2011; Deitz et al., 2015; Lamela et al., 2010).

Studies focused on attachment issues have also been linked to the physical and mental health of individuals. The insecure attachment style, for example, was evidenced in people diagnosed with depression (Garrido et al., 2015), in university students who had difficulties in emotional regulation (Guzmán-González et al., 2016), and in university students who reported minor levels of general physical health (Almeida \& Caldas, 2012). In marital dyads, insecure attachment has been associated with emotional distance between spouses and inflexibility in conflict situations (Sesemann, Kruse, Gardner, Broadbent, \& Spencer, 2017). Finally, 
clinical studies with couples focused on attachment issues have shown a decrease in anxious and avoidant attachment behaviors and an increase in marital satisfaction levels (Moser et al., 2016).

Although there is consistent and convergent scientific literature on the attachment theory and the positive and negative reflexes that the secure and insecure styles, respectively, cause in married life, no studies were found that simultaneously tested the variables mentioned in this study, indicating which ones dichotomously discriminate the attachment style as well as the magnitude of discrimination. Differentiating the group of factors that characterizes each of the attachment styles and indicating which factors have the greatest power of discrimination will be a relevant result that may point to research and intervention agendas for couple psychotherapy.

In this sense, the objective of this study was to assess whether the communication, marital adjustment, resolution, frequency and intensity of conflicts variables would discriminate individuals with secure and insecure attachment in heterosexual relationships. Therefore, the hypothesis tested was that the negative communication, strategies of attack and avoidance, frequency and intensity of conflicts variables would characterize men and women as individuals with insecure attachment, and the open communication, consensus, satisfaction, cohesion and marital adjustment, and the agreement variables would characterize them as individuals with secure attachment styles.

\section{Method}

\section{Participants}

This is a quantitative, cross-sectional study that uses a descriptive and explanatory design. Study participants were 237 men and 248 women $(N=485)$ who were self-declared heterosexual. The minimum age of male applicants was 20 and the maximum was $79(M=42.97 ; S D=12.47)$. The minimum age of female participants was 18 and the maximum was $76(M=40.08 ; S D=11.91)$ (Table 1).

\section{Instruments}

1) Sociodemographic questionnaire: The survey of the sociodemographic characteristics of the participants was carried out through a questionnaire with 14 questions that investigated: age, sexual orientation, place of residence, marital status, length of current relationship, existence of a previous relationship, length of previous relationship, education, working outside the household, workload, personal income, number of children and religion.

2) Experience in Close Relationship - Reduced (ECR-R-Brazil) (Natividade \& Shiramizu, 2015): The scale assesses the anxiety and avoidance of attachment factors in the marital relationship. The ECR-R-Brazil has affirmative phrases that respondents must categorize on a seven-point Likert scale that ranges from "strongly agree" to seven "strongly disagree". The scale has ten items, five on the anxiety factor and five on the avoidance factor. In the analysis of the main components of the items of the ECR-R-Brazil carried out in the study by Natividade and Shiramizu (2015), with good data adequacy, Kaiser-Meyer-Olkin $(K M O)=0.80$; Bartlett's sphericity test, $\chi^{2}(66, N=4.879)=13.309 ; p<0.001$. The final model from the confirmatory factor analysis showed an optimal fit, as pointed out in the study: $\chi^{2}=101.8$; Degrees of freedom $(d f)=25$; $p=<0.001 ; \chi^{2} / d f=4.07$; Goodness-of-Fit Index $(\mathrm{GFI})=0990$; Adjusted Goodness-of-Fit Index $(\mathrm{AGFI})=0.990$; Normed Fit Index $(\mathrm{NFI})=0.990$; Tucker-Lewis Index $(\mathrm{TLI})=0.990$; Comparative Fit Index $(\mathrm{CFI})=0.990$; Root Mean Square Error of Approximation (RMSEA) $=0.025$; Confidence Interval $(C I)=90 \%$. In this study, the ECR-R-Brazil had a Cronbach's Alpha of 0.64 for men and 0.57 for women. 
Table 1

Sociodemographic characteristics of the sample ( $N=485)$. Rio Grande do Sul, Brazil, 2018

\begin{tabular}{|c|c|c|c|c|c|}
\hline \multirow{2}{*}{\multicolumn{2}{|c|}{ Sociodemographic variables }} & \multicolumn{2}{|c|}{ Men } & \multicolumn{2}{|c|}{ Women } \\
\hline & & \multirow{2}{*}{$\frac{N}{29}$} & \multirow{2}{*}{$\begin{array}{c}\text { Frequency \% } \\
12.2\end{array}$} & \multirow{2}{*}{$\frac{N}{10}$} & \multirow{2}{*}{$\begin{array}{c}\text { Frequency \% } \\
4.0\end{array}$} \\
\hline \multirow{5}{*}{ Educational level } & Elementary school & & & & \\
\hline & High school & 64 & 27.0 & 52 & 21.0 \\
\hline & Technical school & 17 & 7.2 & 13 & 5.2 \\
\hline & Higher education & 58 & 24.5 & 70 & 28.2 \\
\hline & Lato and Stricto Sensu postgraduate programs & 69 & 29.1 & 103 & 41.5 \\
\hline \multirow{3}{*}{ Home location } & Porto Alegre & 37 & 15.6 & 37 & 14.9 \\
\hline & Metropolitan region & 32 & 13.5 & 32 & 12.9 \\
\hline & Cities and towns in the countryside of the state & 168 & 70.9 & 179 & 72.2 \\
\hline \multirow{4}{*}{ Marital status } & Civil marriage & 34 & 14.3 & 33 & 13.3 \\
\hline & Religious marriage & 6 & 2.5 & 5 & 2.0 \\
\hline & Civil and religious marriage & 106 & 44.7 & 115 & 46.4 \\
\hline & Living together - stable union & 91 & 38.4 & 95 & 38.3 \\
\hline Length of relationship & Current relationship (years) & $M=15.36$ & $S D=12.08$ & $M=15.32$ & $S D=11.89$ \\
\hline \multirow{2}{*}{ Number of children } & 1 or 2 children & 132 & 55.7 & 147 & 59.3 \\
\hline & 3,4 or 5 children & 27 & 11.4 & 22 & 8.9 \\
\hline \multirow{3}{*}{ Work } & Retired or unemployed & 30 & 12.7 & 49 & 19.8 \\
\hline & Has a job - outside home & 207 & 87.3 & 199 & 80.2 \\
\hline & Working hours outside home & $M=7.26$ & $S D=3.14$ & $M=6.09$ & $S D=3.38$ \\
\hline \multirow{6}{*}{ Income } & No income & 5 & 2.1 & 34 & 13.7 \\
\hline & Up to 1 minimum wage & 10 & 4.2 & 25 & 10.1 \\
\hline & 2 to 3 minimum wages & 83 & 35.0 & 92 & 37.1 \\
\hline & 4 to 6 minimum wages & 68 & 28.7 & 59 & 23.8 \\
\hline & 7 to 10 minimum wages & 40 & 16.9 & 25 & 10.1 \\
\hline & +11 minimum wages & 31 & 13.1 & 13 & 5.2 \\
\hline \multirow{5}{*}{ Religion } & Catholic & 167 & 70.5 & 165 & 66.5 \\
\hline & Evangelical Christian & 25 & 10.5 & 23 & 9.3 \\
\hline & Kardecist spiritism & 21 & 8.9 & 37 & 14.9 \\
\hline & Protestant & 4 & 1.7 & 6 & 2.4 \\
\hline & No religion & 20 & 8.4 & 17 & 6.9 \\
\hline
\end{tabular}

Note: M: Mean; SD: Standard Deviation.

3) Marital Conflict Scale (Mosmann, Wagner, \& Sarriera, 2008): The conflict scale is divided into two subscales: in the first, called "conflict-disagreement", nine items are presented and must be assessed on a six-point Likert scale regarding the frequency with which the reasons for disagreement indicated occurred in the last year, ranging from "almost never" to six "almost every day". In the second subscale, called "conflict-aggression", three items are presented referring to the intensity of conflicts, these must be assessed on a Likert scale of five points ranging from "never" to five "always". In the study to adapt the scale from English to Portuguese, a Cronbach's Alpha of 0.71 was found. In this study, Cronbach's values were 0.80 for men and 0.77 for women.

4) Conflict Resolution Behavior Questionnaire (Delatorre \& Wagner, 2015): The questionnaire has 22 items through which conflict resolution strategies are assessed on a five-point Likert scale, ranging from "never" to "always". The questionnaire is divided into three factors: attack, consisting of nine items referring to behaviors that involve physical and verbal abuse to the spouse; avoidance, composed of eight items referring to the removal of conflict or suppression of feelings; and agreement, composed of five items that include negotiation, joint discussion of conflicts and conciliation behaviors. In the adaptation study by Delatorre \& Wagner (2015), Cronbach's Alpha values were 0.70 for the avoidance factor, 0.79 for the attack 
factor and 0.68 for the agreement factor. In this study, Cronbach's Alpha values for men and women were 0.76 and 0.74 , respectively, in the avoidance factor, 0.74 and 0.73 in the attack factor, and 0.77 and 0.77 in the agreement factor.

5) Communication Questionnaire (Luz \& Mosmann, 2018): It is a questionnaire consisting of 15 items divided into two factors. The first has nine items that assess negative communication and the second has six items that assess open communication. The respondents marked their answers on a Likert scale of seven points ranging from "not applicable" to seven "very applicable", how each statement corresponds to the way their marital spouses communicate. In the study for the Brazilian adaptation of the scale, Cronbach's Alpha was found to be 0.74 for negative communication and 0.70 for open communication (Luz \& Mosmann, 2018). In this study, Cronbach's Alpha values for the negative communication and open communication factors were, respectively, 0.86 and 0.81 for men and 0.83 and 0.83 for women.

6) Revised Dyadic Adjustment Scale (Hollist et al., 2012): The reduced version of the marital adjustment scale has 14 items that constitute three factors. The first one, consensus, has six items that assess the level of agreement/disagreement between spouses on different issues, on a six-point Likert scale ranging from five "we always agree" to zero "we always disagree". The satisfaction factor has four items that measure the frequency with which spouses fight, talk about divorce, among other topics, on a six-point Likert scale ranging from zero "always" to five "never". The third factor, cohesion, has four items to assess the frequency with which spouses carry out different activities together. Items must be scored on a six-point Likert scale ranging from zero "never" to five "more than once a day", except for item 11 which is scored on a five-point Likert scale, corresponding to "every day" and "never". In the translation and validation for Brazil, Cronbach's Alpha was found to be 0.90 for total adjustment, 0.81 for the consensus, 0.85 for the satisfaction and 0.80 for the cohesion factors. In this study, Cronbach's Alpha values for total adjustment and the consensus, satisfaction and cohesion factors, were $0.84,0.77,0.78$ and 0.80 , respectively, for men and $0.87,0.72,0.83$ and 0.82 for women.

\section{Procedures}

Data collection took place in the city of Porto Alegre, metropolitan region and cities and towns in the countryside of the state of Rio Grande do Sul, Brazil, for the sample to be heterogeneous. The responsible researcher contacted the respondents via telephone, messaging apps and e-mail, through people whom these people already knew, churches and psychology schools, therefore, data collection for convenience. In the first contact the researcher explained the objectives of the study, as well as the risks and benefits involved in the participation. If the person was interested and available for an interview, a day and time was scheduled for data collection at the respondent's preferred location, which varied between their households and workplaces. The procedure took an average of 60 minutes and involved reading aloud the Informed Consent Term, clarifying doubts, signing the Informed Consent Term in two hard copies, one for the participant and another for the researcher who kept the document in an envelope. separated from their other materials, to avoid identifying the respondent by the signed term sheet and filling out the research questionnaire.

The present study was submitted to the evaluation of the Research Ethics Committee of the Universidade do Vale do Rio dos Sinos (UNISINOS, University of Vale do Rio dos Sinos) and approved, as stated in the opinion number 2.075.195 (CAAE n 65851616.6.0000.5344). The procedures adopted strictly followed what is contained in Resolution 510/2016 of the National Health Council, considering the pertinent

6 ethical and scientific foundations, as stated in the Informed Consent Term. 


\section{Data analysis}

Initially, a database was built using the IBM ${ }^{\circledR}$ SPSS ${ }^{\circledR}$ (version 25.0) Software and information from data collection was entered into the system. First, the sample's normality criteria were verified and then descriptive analyzes were performed to calculate percentages, averages and standard deviations, and parametric analyzes to calculate the cutoff point for the Attachment Scale - ECR-R-Brazil. Considering the significance level of $95 \%(p \leq 0.05)$, a discriminant analysis was carried out using a dichotomous dependent variable, in this study, secure and insecure attachment styles, in order to characterize/ discriminate these two groups by independent variables (Hair, Black, Babin, Anderson, \& Tatham, 2009). According to the authors, the sample calculation for performing discriminant analysis provides for a minimum of five observations for each independent variable and a minimum of 20 observations per discriminated group. The independent variables were intensity and frequency of conflicts, negative and open communication, avoidance, attack and agreement as strategies for conflict resolution, consensus, satisfaction, cohesion and marital adjustment. Therefore, a total of 11 independent variables required a minimum of 55 observations.

The characterization of the type of attachment of men and women followed the patterns of the adaptation study conducted by Natividade and Shiramizu (2015), in which the percentile below 30 in the anxiety and avoidance factors meant that these individuals had a secure attachment style and the percentile above 70 meant that these individuals had an insecure attachment style. The cases scoring between 30 and 70 in the percentile range were not considered in the analysis. Still, the authors recommend that men and women be analyzed separately, since there may be a variation in the results.

\section{Results}

Based on the aforementioned classification, the results indicated 80 excluded cases and 157 valid cases in the male group. Of the valid cases, $52.2 \%(n=82)$ had secure attachment relationships and $47.8 \%$ ( $n=75$ ) insecure attachment relationships. In the group of women, 84 cases were excluded and 164 were valid cases, with $46.3 \%(n=76)$ presenting secure attachment relationships and $53.7 \%(n=88)$ insecure attachment relationships.

The cutoff point established for the variables with the greatest discriminating power was $\geq 0.30$ (Sarriera et al., 2012). The centroid values, negative and positive, indicate the independent variables that characterized the group of men and women with secure and insecure attachment styles. For men, the centroid values were: $F=-0.79$ for secure attachment and $F=0.86$ for insecure attachment, while for women they were: $F=0.92$ for secure attachment and $F=-0.77$ for insecure attachment. The Function Values $(F)$ indicate that, for men, negative values correspond to the independent variables that characterize secure attachment, and positive values refer to the variables that characterize an insecure attachment style. The opposite is true for women, negative values correspond to the independent variables that characterize insecure attachment, and positive values to the variables that characterize a secure attachment style (Table 2).

Table 2

Function values. Rio Grande do Sul, Brazil, 2018

\begin{tabular}{lccccccccc}
\hline & Function & Face value & Variance $\%$ & Cumulative variance & Canonical correlation & $\lambda$ Wilks & $\chi^{2}$ & $d f$ & $p$ \\
\hline Men & 1 & 0.69 & 100.0 & 100.0 & 0.64 & 0.59 & 79.14 & 10 & 0.000 \\
Women & 1 & 0.74 & 100.0 & 100.0 & 0.65 & 0.57 & 87.44 & 10 & 0.000 \\
\hline
\end{tabular}


The results of the analysis of the results obtained by the male participants showed that the 11 independent variables of the study had a magnitude higher than the established cutoff point (load $\geq 0.30$ ) in the discrimination of the groups. The marital adjustment (-0.72), consensus (-0.69), open communication $(-0.48)$, cohesion $(-0.46)$, satisfaction $(-0.43)$ and agreement $(-0.37)$ variables discriminated the group with a secure attachment style, and the negative communication (0.76), avoidance (0.54), attack (0.46), frequency of marital conflict $(0.38)$ and intensity of marital conflict $(0,34)$ variables discriminated the group with an insecure attachment style.

For women, the groups of secure and insecure attachment were discriminated by the same variables, however, there was a difference in the magnitude of the discrimination. The marital adjustment (0.82), open communication (0.71), cohesion (0.69), consensus (0.66), satisfaction (0.54) and agreement (0.36) variables discriminated the group with a secure attachment style, and the negative communication (-0.56), avoidance $(-0.54)$, frequency of marital conflict $(-0.46)$, attack $(-0.32)$ and intensity of marital conflict $(-0.30)$ variables discriminated the group with an insecure attachment style (Table 3).

Table 3

Structure matrix. Rio Grande do Sul, Brazil, 2018

\begin{tabular}{lccc}
\hline Variables & Function 1 Men & Variables & Function 1 Women \\
\hline Negative communication & 0.76 & Marital adjustment & 0.82 \\
Marital adjustment & -0.72 & Open communication & 0.71 \\
Consensus & -0.69 & Cohesion & 0.69 \\
Strategies of avoidance & 0.54 & Consensus & 0.66 \\
Open communication & -0.48 & Negative communication & -0.56 \\
Strategies of attack & 0.46 & Strategies of avoidance & -0.54 \\
Cohesion & -0.46 & Satisfaction & 0.54 \\
Satisfaction & -0.43 & Frequency of marital conflict & -0.46 \\
Frequency of marital conflict & 0.38 & Agreement & 0.36 \\
Agreement & -0.37 & Strategies of attack & -0.32 \\
Intensity of marital conflict & 0.34 & Intensity of marital conflict & -0.30 \\
\hline
\end{tabular}

\section{Discussion}

The aim of this study was to assess whether the communication, marital adjustment, frequency, intensity and resolution of conflicts variables discriminate individuals with secure and insecure attachment in heterosexual relationships. The hypothesis that the negative communication, strategies of attack and avoidance, frequency and intensity of conflicts variables would characterize men and women with an insecure attachment style, and that the open communication, consensus, satisfaction, cohesion and marital adjustment and agreement variables would characterize those with a secure attachment style was confirmed. Therefore, the results will be discussed from the variables with the greatest discriminating power to those with the least discriminating power in each group.

The variables that characterized the attachment styles of men and women were above the established cutoff point, showing a satisfactory discriminating power. This result confirms previous studies regarding the marital relationship variables that are relevant, and which should be highlighted in scientific research (Cobb et al., 2001; Costa et al., 2017; Scheeren et al., 2014; Scheeren et al., 2015; Wiebe \& Johnson, 2016). Focusing on such aspects can contribute to empirical evidence to support the development of interventions, especially in couple psychotherapy, serving as a plan

8 for professionals. 
The variable with the greatest discrimination power for secure attachment was marital adjustment for men and women. This result may indicate that perceiving yourself as adjusted to the relationship is a characteristic of individuals who have a role model of secure attachment (Cobb et al., 2001; Consoli et al., 2018). Considering that these are self-report scales, it is possible to mention that individuals with a secure attachment style, that is, who can clearly express their emotional needs, be empathetic, responsive and alternate between the ability to protect and to be protected (Bowlby, 1973/2004; Lamela et al., 2010), are those with the highest levels of marital adjustment. Although it is not possible to reflect on a cause and effect relationship, the attachment style is constituted before the marital relationship, therefore, it is conjectured that secure attachment contributes to the individual establishing satisfactory levels of adjustment with the spouse and make a more positive assessment of their conjugality (Curran et al., 2011; Deitz et al., 2015; Mikulincer et al., 2002; Walsh, 2016). Still, considering the reverberation that the characteristic behaviors of secure attachment cause in spouses and the feedback inherent to the dyad, the responses are always reinforcing more positive and protective perceptions in crisis situations, since the basis of the relationship was constituted in an emotionally safe way.

The consensus, cohesion and marital satisfaction variables had similar discriminating power between men and women, although for them the consensus is of greater magnitude, followed by open communication, cohesion and satisfaction and agreement. For them, open communication had a greater discriminating magnitude, followed by cohesion, consensus, satisfaction and agreement. This result may indicate that consensus building, that is, the ability to ponder what is important to you and to the other one, characterizes men with a secure attachment style. This aspect corroborates other studies about what is expected from individuals with the said attachment style and can be considered as a constructive strategy for resolving marital conflicts (Corcoran \& Mallinckrodt, 2000; Curran et al., 2011; Scheeren et al., 2014; Scheeren et al., 2015;). Equivalent interpretation can be done with open communication, a variable that provides the ability to talk in an assertive, respectful and empathic way, therefore, a congruent result in the male group.

For women, open communication showed a greater discriminating power of secure attachment, confirming what other studies have pointed out that individuals with that attachment style communicate to their spouses what they are thinking and feeling, since they trust in their ability to help them. them and understand them (Cobb et al., 2001; Lamela et al., 2010). For them, cohesion had a higher discriminating magnitude than men, which may indicate a difference previously found in other studies (Curran et al., 2011; Epstein et al., 2013), in which men are guided mainly by aspects rational ways of resolving marital conflicts, like consensus, while women are guided by emotional aspects, in this case, through cohesion, a variable that measures the level of emotional closeness and affinity between spouses (Hollist et al., 2012).

Marital satisfaction and the strategy of agreement in resolving conflicts characterized the style of secure attachment of men and women of similar magnitude. The result corroborates what has been pointed out in Brazilian and international studies (Cobb et al., 2001; Consoli et al., 2018; Corcoran \& Mallinckrodt, 2000; Scheeren et al., 2014; Scheeren et al., 2015; Semensato \& Alves, 2013) that people with secure attachment tend to perceive the relationship as more positive and to resort to constructive strategies to resolve marital conflicts. In addition to perception, the secure attachment style tends to be an internal mechanism that allows individuals, even in situations of suffering, crisis and danger, to remain emotionally stable, aware and confident of their own ability to manage setbacks and pains. In addition, they feel safe with their spouses, since this condition depends initially on an intrapersonal security base to later become an interpersonal security base.

The variables that stood out for men with a higher magnitude in discriminating the style of insecure attachment were negative communication, and avoidance and attack strategies in agreement. Again, results are congruent, since negative communication involves blaming, overdoing, moving away, among other destructive strategies (Delatorre \& Wagner, 2015; Scheeren et al., 2015; 2014). The frequency with which men perceive conflicts involving issues such as children, free time, money, domestic chores, family of origin, 
individuality, work, among others, and the intensity of the discussion involving such themes characterized men with an insecure attachment style. This result may indicate the effective presence of high levels of conflict or that the respondent's given a biased, negative assessment, which can occur if their role model is insecure attachment (Mikulincer et al., 2002; Murray et al., 2000).

For women, an insecure attachment style was mainly discriminated by the negative communication variable, followed by the avoidance strategy, frequency of conflicts, attack strategy and intensity of the marital conflict variables (Corcoran \& Mallinckrodt, 2000; Curran et al., 2011; Scheeren et al., 2014; Scheeren et al., 2015). As mentioned in the case of men, the variables that discriminated against an insecure attachment style in women confirm what was found in other studies about the characteristics that permeate the marital relationship and the perception of individuals who have a role model of insecure attachment (Mikulincer et al., 2002; Murray et al., 2000).

This result promotes reflections about the impact that the insecure attachment style causes at the intrapersonal level, reverberating in the dyad. Such repercussions lead to discussions that go beyond attachment issues since they interfere with the entire repertoire of responses and resources that each spouse will use to interact with their spouses. It is conjectured, therefore, the need for two movements: to understand the process that begins with the base of insecure attachment and to identify the responses that are consistent with that style of attachment. In this sense, changing the responses can be an alternative to the attempt of transforming the interaction between the spouses and, consequently, foster higher levels of functionality in the marital relationship.

In addition, an intragroup observation shows that the variables with higher magnitude for men were those that mainly discriminated against the insecure attachment style while, for women, they were those that discriminated against secure attachment. Although it is not possible to state that this represents a statistically significant difference between men and women, as found by Deitz et al. (2015), the result may indicate that destructive strategies in conflict resolution, such as negative communication and avoidance, prevail if the attachment style is insecure. This finding may suggest that, in the group composed of men, the discrimination of the negative aspects stands out compared to the discrimination of the positive aspects. This result can be explained by the superior impact of negative aspects on individuals' physical and mental health (Almeida \& Caldas, 2012; Guzmán-González et al., 2016), plus the lesser male ability to manage emotional issues, resulting the family and social context - which do not contribute to the development of these skills in men, causing this issues to be perceived by them as more frightening and destructive ones.

In the case of women, marital adjustment, open communication, cohesion and consensus were greater than the variables that discriminated against an insecure attachment style. This result may suggest that women in the secure attachment style group and who positively assess their relationships feel more emotionally comfortable and, therefore, perceive the relationship as more secure when compared to women in the group with an insecure attachment style. Still, individuals in the insecure attachment group tend not to highlight the negative aspects even if they have insecurity in relation to their bonds, differently from what may have happened with men from both groups and women from the secure attachment group. One hypothesis for this result is that these women, precisely because they feel insecure, decline a more rigorous assessment because they may not be able to perceive themselves in a more functional relationship and/or even if they have positive expectations, they may not have individual conditions to improve their relational dimensions.

\section{Conclusion}

The results found in the present study confirmed that the aspects investigated are effectively relevant 
styles. Considering the importance of assessing marital dynamics in clinical work, this result can assist in identifying the demands of the couple and each spouse. This is because a role model of an insecure attachment style can be characteristic of individuals who negatively assess their relationships and spouses, communicate negatively, use destructive strategies to resolve conflicts and perceive marital conflicts as frequent and intense.

In addition, on self-report scales, the respondents analyzed different areas of the relationship and marital dynamics, and the assessment may or may not be equivalent to that of their spouses. Such differences may point to cases in which the individual analysis corresponds more to a secure or an insecure attachment role model of the individual who is answering the questionnaire, than to what actually happens in the relationship. In these cases, allowing the couple to bring their assessments closer, re-signifying negative perceptions, which are characteristic to an insecure attachment style constituted in the individual's first bonding experiences, would promote closeness and intimacy between the couple. This would be because the spouses would better understand how the other one thinks and feels in relation to marital issues and would allow them to focus on the details of what brought them together, of each member of the dyad and the conjugal dynamics that trigger different perceptions and behaviors.

The objective proposed in this study has been achieved and the results provide subsidies to better understand and intervene in the demands of individuals and couples who face relationship difficulties. Clarifying that certain individual and interpersonal characteristics are interconnected and can be perceived through behaviors and dynamics that are established between spouses is essential for the assessment process in couple therapy to be reliable and the intervention to be effective. Still, clinical and investigative work focused on attachment is a current approach and leads to more and more evidence of efficacy and effectiveness in the field, especially as it is an inseparable construct of the conjugal experience that essentially provides for intimacy, openness and empathy and in which individuals can show their vulnerable side, trust each other, receive support, security and protection.

Finally, the limitations of the study involve the decision for a type of statistical analysis that made it impossible to specify the results about the insecure attachment style, which can characterize anxious or avoidant individuals. Although such attachment styles also trigger negative individual and dyadic processes, there is a difference in how people with this type of attachment express their insecurity, resolve marital conflicts and perceive their spouses and their relationship. Further studies can explore other forms of analysis that can even characterize the sample of individuals who were not included in the analysis because they were outside the percentile established as the cutoff point in this study, an aspect that can be precisely explained because the researchers opted for a dichotomous classification of secure and insecure attachment.

\section{Contributors}

All authors contributed equally to the conception and design, analysis and interpretation of data, discussion of results, review and approval of the final version of the article.

\section{References}

Ainsworth, M. D. S. (1985). Attachment across the lifespan. Bulletin of the New York Academy of Medicine, 61, 792-811.

Almeida, L. M. M. F., \& Caldas, J. M. P. (2012). Intimidade e saúde. Psicologia USP, 23(4), 737-755. http://dx.doi. org/10.1590/S0103-65642012000400007

Bowlby, J. (2004). Apego e perda: tristeza e depressão (3a ed.). São Paulo: Martins Fontes. (Publicado originalmente em 1973).

Cobb, R. J., Davila, J., \& Bradbury, T. N. (2001). Attachment security and marital satisfaction: the role of positive perceptions and social support. Personality and Social Psychology Bulletin, 27(9), 1131-1143. http://dx.doi. org/10.1177/0146167201279006 
Consoli, N., Wagner, B. J., \& Marin, A. H. (2018). Laços de afeto: as repercussões do estilo de apego primário e estabelecido entre casais no ajustamento conjugal. Avances en Psicología Latinoamericana, 36(2), 315-329. http:// dx.doi.org/10.12804/revistas.urosario.edu.co/apl/a.5409

Corcoran, K. O. C., \& Mallinckrodt, B. (2000). Adult attachment, self-efficacy, perspective taking, and conflict resolution. Journal of Counseling \& Development, 78(4), 473-483. http://dx.doi.org/10.1002/j.1556-6676.2000.tb01931.x

Costa, C. B., Delatorre, M. Z., Wagner, A., \& Mosmann, C. P. (2017). Terapia de casal e estratégias de resolução de conflito: uma revisão sistemática. Psicologia: Ciência e Profissão, 37(1), 208-223. http://dx.doi.org/10.1590/19823703000622016

Curran, M., Ogolsky, B., Hazen, N., \& Bosch, L. (2011). Understanding marital conflict 7 years later from prenatal representations of marriage. Family Process, 50(2), 221-234. http://dx.doi.org/10.1111/j.1545-5300.2011.01356.x

Deitz, S. L., Anderson, J. R., Johnson, M. D., Hardy, N. R., Zheng, F., \& Liu, W. (2015). Young romance in China: effects of family, attachment, relationship confidence, and problem solving. Personal Relationships, 22(2), 243-258. http:// dx.doi.org/10.1111/pere. 12077

Delatorre, M. Z., \& Wagner, A. (2015). Estratégias de resolução de conflitos conjugais: evidências de validade do CRBQ. Avaliação Psicológica, 14(2), 233-242. http://dx.doi.org/10.15689/ap.2015.1402.08

Epstein, R., Warfel, R., Johnson, J., Smith, R., \& McKinney, P. (2013). Which relationship skills count most? Journal of Couple and Relationship Therapy, 12(4), 297-313. http://dx.doi.org/10.1080/15332691.2013.836047

Garrido, L., Guzmán-González, M., Santelices, M. P., Vitriol, V., \& Baeza, E. (2015). Estudio comparativo de los estilos de apego adulto en un grupo de mujeres con y sin diagnóstico de depresión. Terapia Psicológica, 33(3), 285-295. http// dx.doi.org/10.4067/S0718-48082015000300011

Guzmán-González, M., Carrasco, N., Figueroa, P., Trabucco, C., \& Vilca, D. (2016). Estilos de apego y dificultades de regulación emocional en estudiantes universitarios. Psykh, 25(1), 1-13. http://dx.doi.org/10.7764/psykhe.25.1.706

Hair, J. F., Black, W. C., Babin, B. J., Anderson, R. E., \& Tatham, R. L. (2009). Análise multivariada dos dados. Porto Alegre: Bookman.

Hardy, N. R., \& Fisher, A. R. (2018). Attachment versus differentiation: the contemporary couple therapy debate. Family Process, 57(2), 557-571. http://dx.doi.org/10.1111/famp.12343

Hollist, C. S., Falceto, O. G., Ferreira, L. M., Miller, R. B., Springer, P. R., Fernandes, C. L. C., \& Nunes, N. A. (2012). Portuguese translation and validation of the Revised Dyadic Adjustment Scale. Journal of Marital and Family Therapy, 38(1), 348-358. http://dx.doi.org/10.1111/j.1752-0606.2012.00296.x

Lamela, D., Figueiredo, B., \& Bastos, A. (2010). Adaptação ao divórcio e relações coparentais: contributos da teoria da vinculação. Psicologia: Reflexão e Crítica, 23(3), 562-574. Recuperado em http://www.redalyc.org/articulo. oa? id=18818719017

Luz, S. K., \& Mosmann, C. P. (2018). Funcionalidade e comunicação conjugal em diferentes etapas do ciclo de vida. Revista da SPAGESP, 19(1), 21-34. Recuperado de http://pepsic.bvsalud.org/scielo.php?script=sci_ arttext\&pid=S1677-29702018000100003 \&lng=pt\&tlng=pt

Mikulincer, M., Florian, V., Cowan, P. A., \& Cowan, C. P. (2002). Attachment security in couple relationships: a systemic model and its implications for family dynamics. Family Process, 41(3), 405-434. http://dx.doi.org/10.1111/j.15455300.2002.41309.x

Moser, M. B., Johnson, S, M., Dalgleish, T. L., Lafontaine, M., Wiebe, S. A., \& Tasca, G. A. (2016). Changes in relationshipspecific attachment in emotionally focused couple therapy. Journal of Marital and Family Therapy, 42(2), $231-245$. http://dx.doi.org/10.1111/jmft.12139

Mosmann, C., Wagner, A., \& Sarriera, J. (2008). A qualidade conjugal como preditora dos estilos educativos parentais. Revista Psicologia Lisboa, 22(2), 161-182. Recuperado de http://revista.appsicologia.org/index.php/rpsicologia/article/ view/352

Murray, S. L., Holmes, J. G., \& Griffin, D. W. (2000). Self-esteem and the quest for felt security: how perceived regard regulates attachment processes. Journal of Personality and Social Psychology, 78(3), 478-498. http://dx.doi. org/10.1037/0022-3514.78.3.478

Natividade, J. C., \& Shiramizu, V. K. M. (2015). Uma medida de apego: versão brasileira da Experiences in Close Relationship Scale-Reduzida (ECR-R-Brasil). Psicologia USP, 26(3), 484-494. http://dx.doi.org/10.1590/0103-656420140086

Ricco, R. B., \& Sierra, A. (2017). Argument beliefs mediate relations between attachment style and conflict tactics. Journal of Counseling \& Development, 95(2), 156-167. http://dx.doi.org/10.1002/jcad.12128 
Sarriera, J. C., Ximenes, V. M., Bedin, L., Rodrigues, A. L., Schütz, F. F., Montserrat, C., \& Silva, C. L. (2012). Bem-estar pessoal de pais e filhos e seus valores aspirados. Aletheia, 37, 91-104. Recuperado de http://pepsic.bvsalud.org/pdf/ aletheia/n37/n37a07.pdf

Scheeren, P., Delatorre, M. Z., Neumann, A. P., \& Wagner, A. (2015). O papel preditor dos estilos de apego na resolução do conflito conjugal. Estudos e Pesquisas em Psicologia, 15(3), 835-852. Recuperado de http://pepsic.bvsalud.org/ scielo.php?script=sci_arttext\&pid=S1808-42812015000300004

Scheeren, P., Vieira, R. V. D., Goulart, V. R., \& Wagner, A. (2014). Marital quality and attachment: the mediator role of conflict resolution styles. Paidéia, 24(58), 177-186. http://dx.doi.org/10.1590/1982-43272458201405

Seedall, R. B., \& Lachmar, E. M. (2016). Attachment-related dynamics during a positively themed couple interaction: implications of anxiety and avoidance. Couple and Family Psychology: Research and Practice, 5(1), 27-42. http:// dx.doi.org/10.1037/cfp0000054

Semensato, M. R., \& Alves, C. A. (2013). O script de apego compartilhado no casal. Arquivos Brasileiros de Psicologia, 65(1), 138-151. Retrieved from https://www.redalyc.org/pdf/2290/229028925010.pdf

Sesemann, E. M., Kruse, J., Gardner, B. C., Broadbent, C. L., \& Spencer, T. A. (2017). Observed attachment and selfreport affect within romantic relationships. Journal of Couple \& Relationship Therapy, 16(2), 102-121. http://dx.doi. org/10.1080/15332691.2016.1238794

Walsh, F. (2016). Visões clínicas de normalidade, saúde e disfunção familiar. In F. Walsh (Org.), Processos normativos da familia: diversidade e complexidade (4a. ed., pp.57-77). Porto Alegre: Artmed.

Wiebe, S. A., \& Johnson, S. M. (2016). A review of the research in emotionally focused therapy for couples. Family Process, 55, 390-407. http:/dx.doi.org/10.1111/famp.12229

Received: April 17, 2019

Final version: February 20, 2020

Approved: April 7, 2020 